\title{
SME Perceptions of and Responses to the Recession
}

\author{
Liz Price, David Rae and Veronica Cini
}

\author{
Final manuscript submitted to Journal of Small Business and Enterprise Development, February \\ 2013 (due for publication in Volume 20, Issue 2)
}

\section{Introduction}

The UK has recently experienced the worst recession since the 1930s. The initial economic crisis, which saw a 7\% decline in output between the first quarter of 2008 and the end of 2009 (ONS, 2012a), has been followed by a prolonged period of low and negative growth. This led to the UK reentering recession in early 2012. At the same time, forecasts for GDP growth in the UK were revised downwards by the International Monetary Fund (IMF, 2012) due to the severe effect of the global economic crisis on the UK financial sector. There continue to be concerns that a flat lining economy will become the "new normal" (Davis, 2009).

Despite the severity of this recent recession, there are currently few studies of its effect on small and medium-sized enterprises (SMEs). However, small business growth and entrepreneurship are recognised as essential drivers for economic recovery (Matlay, 2012; Rae, 2010). Drawing on an online bi-monthly survey of SMEs in Lincolnshire and Rutland, this paper explores owner managers' perceptions of the UK recession. We examine the views of businesses on various aspects of the recession, and how this has affected business performance, levels of confidence, and growth ambitions. The paper explores the role of business confidence in the economy as a determinant of business growth intentions, and draws a comparison between perceptions and behaviour.

The paper first outlines relevant literature on the effect of recession on SMEs, and owner manager strategies to respond to recession. It then provides a methodology which describes the survey design and sampling approach, and some context for the area where the survey was undertaken. The findings section sets out the key results of the survey. The discussion and conclusions sections relate the findings to broader debates on the economy, and draw out recommendations for how SMEs might be better supported during recession.

\section{Literature Review}

Resilience, which can be defined as "the process of adapting well in the face of adversity" (de Jorge Moreno et al, 2007) and the survivability of SMEs during recession, are thought to be related to a number of factors that are internal and external to the firm. These include the severity of the economic crisis and the environmental context of the SME, as well as the individual strategies undertaken by SME owner-managers. Drawing on the literature, we first examine the effect of the latest recession on SMEs before considering the role of SME owner-managers' response.

\section{The effect of the Recession on SMEs}

The 2008-09 recession took place alongside a global recession and, unlike the previous two recessions, the financial sector is identified as the source of the crisis (Athey, 2009; Hills et al, 2010). Chow and Dunkelburg (2011) suggest that recessions initiated by financial crises are unusually severe, and affect the small business sector disproportionately. In the 2008-09 recession, the financial crisis brought about restricted access to mortgage loans and finance for new construction projects. This initiated an early decline in the construction sector, in which SMEs account for $85 \%$ of total employment (BIS, 2011). Output in this sector contracted by $11 \%$ between 2008 and 2009 (ONS, 2011), and was accompanied by shrinkage in demand for professional services, such as property, financial, recruitment and transport services (Bank of England, 2009). More generally, reduced availability of finance affected the SME sector disproportionately, as small firms were identified as a greater investment risk than larger firms (Sahin et al, 2011; Taylor \& Bradley, 1994). Late payment of debts is also thought to have severely affected SMEs, and the cash flow of small companies in particular, during the recession (Paul and Boden, 2011). 
The depth of the 2008-09 recession, and the measures taken to alleviate its effects, such as reducing the VAT rate and providing unemployment benefits, has left the UK with a large public sector deficit of $£ 15$ bn (OBR, 2011). Plans to reduce this deficit have clear implications for SMEs that are reliant on expenditure of public sector employees, or on contracts with public sector organisations. In 2010 the Government announced that 192 public bodies, or quangos, would be abolished (Cabinet Office, 2011). A report by PWC (2010) estimates that knock-on effects of public sector cuts could include a loss of $3.2 \%$ of private sector employment, or 925,000 jobs. These are likely to affect business services, construction, and manufacturers disproportionately (ibid). More widely, falling sales stemming from reduced consumer demand has affected SMEs across the manufacturing and retail sectors (Sahin et al, 2011). The manufacturing sector had its most significant slowdown towards the end of 2008, although started to recover during 2009 as depreciation of sterling assisted the growth of export activities. A decline in consumer spending affected the retail sector from the end of 2008 and this sector continues to be subdued long into the recovery (Bank of England, 2011).

While SMEs in the construction, business services and manufacturing sectors have been affected by the recent recession, a number of studies suggest that other sectors may be more immune. Across both the 1990-92 and 2008-09 recessions primary industries, such as oil production and agriculture, have proved less vulnerable than other sectors (Audas and Mackay, 1997; Taylor and Bradley, 1994). The food sector generally has proved resilient to recession, illustrated by the expansion of supermarkets throughout the period (Athey, 2009; Simons, 2009).

As well as having a differential effect on the size and sector of SMEs, the location and environmental context of an SME also plays a role in its resilience to recession (Dixon, 2007). Martin (2011) shows that the economic structure of a region - how diverse its structure is, the skills of its workforce, its entrepreneurial culture, and economic governance arrangements - affects its response to economic shocks. The 2008-09 recession is expected to affect SMEs in peripheral regions, such as the North East, Scotland, Wales and Northern Ireland, most in the longer term as these are the areas with the highest proportions of public sector employment (PWC, 2010).

\section{Strategies of SME Owner Managers}

There is some debate in the literature about the extent to which the actions of owner managers influence the survival of SMEs in a recession. Some argue that SMEs have less control over their external environment when compared with larger firms (Smallbone et al, 1999), and that they perceive recessions as "an externally controlled condition over which they have no control" (Stone, 1975: 1). Whether this lack of control is real or perceived, both are likely to affect the ability of SME owner managers to respond to recession.

Others argue that survival of smaller firms is assisted by the instincts of owner managers, who are likely to see the success of their business as personal as well as commercial goal. Anderson \& Russell (2009: 11) show, from their survey of small UK businesses during recession, that many exhibit resilience, flexibility, adaptability and absorptive capacity underpinned by personal sacrifices of the owners: "survival, almost regardless of personal cost, is instinctive".

The owner-manager strategies identified in the literature can broadly be grouped into those that involve reducing costs in order to survive recession or that focus on growth in order to retain capacity for when the recession is over. Cost cutting approaches include downsizing the workforce, reducing products, reducing stock, and freezing pay, while growth related approaches include offering new/improved products, competing on price, and acquiring other firms that have been weakened by recession (Stone, 1975; Judd and Lee, 1981).

In terms of revenue-generating approaches, a study of SME responses to the 2008-09 recession by Kitching et al (2011) found that market and product diversification, including the introduction of new goods/services and attraction of new customers, was the most successful form of SME response. Some SMEs have been rewarded from focusing on the changing needs of consumers during the recession. These include providers of cheaper transport options, indulgence goods and home entertainment systems, as well as services for those that have fallen on difficult times such as 
discount retailers and pawn brokers (Social Issues Research Centre, 2009; Piercy et al, 2010). The recent growth in export activities reflects diversification into new international markets, prompted by favourable exchange rates (Oxford Economics, 2009). Periods of recession and recovery may also provide an opportune time for new business creation and expansion. Rae (2010) cites evidence that start-up rates tend to increase during recession, partly due to redundancy, necessity entrepreneurship, and the freeing-up of human capital from organisations that are downsizing. Even during recession, Rae et al (2012: 486) suggest there is "the potential for entrepreneurial spirits to pursue opportunities counter-cyclically by creating their own confidence and bootstrapping their resources".

Cost cutting approaches have been evident in the construction and manufacturing sectors, with many SMEs asking employees to reduce their working hours, take temporary pay cuts, or unpaid leave to survive a period of declining activity (Athey, 2009). The Federation of Small Business shows that around $20 \%$ of small businesses have been able to grow their profitability during the recession, partly because of pay freezes and job cuts (FSB, 2011). SMEs are also more likely to take a cost cutting approach to finance; with many seeking funds internally or from family sources, thereby reducing their dependence on external finance which may be more difficult obtain (Cosh et al, 2008).

\section{Confidence and Expectations}

Confidence in economic conditions, and expectations about future sales, are identified as key drivers of SME investment and growth (Chow and Dunkelburg, 2011). Wheeler (2010) shows that, according to key national business surveys, both the 2008-9 and 1990-2 recessions were preceded by a fall in business expectations. For this reason, SME perceptions about the growth of the economy - whether entirely accurate or not - can be regarded as one indicator of prospective business growth and worthy of further analysis.

There are a number of reasons, however, why measures of business confidence and expectations gathered via surveys need to be used with caution. Storey (2011) shows that small business owners are considerably more optimistic than those that are employed. This optimism is thought to be related to greater levels of self-confidence among SME owner managers (de Jorge Moreno et al, 2007), and can mean that business owners are likely to report higher expectations than others that work in the SME sector. Conversely, Wheeler (2010) shows that business owners often overestimate the prospective effects of key events (as in the example of the 911 terrorist attacks, which had less effect on the global economy than predicted by business surveys). It can therefore be difficult in practice to isolate where changing business expectations are a signal for a recession or simply a false signal. Media coverage in general may also contribute to business perceptions. In a survey conducted by the Social Issues Research Centre (2009), 40\% of respondents considered that the media had exaggerated the effects of the recession, and played on people's fears unnecessarily.

Even taking into account the risks associated with use of business surveys, a number of UK surveys provide a consistent and similar picture of business confidence. National surveys undertaken by the Federation of Small Business (FSB) and British Chamber of Commerce both suggest that small business confidence has declined beyond the 2008-09 recession, which reflects the prolonged period of low and negative growth following the initial economic crisis. The FSB survey, which was undertaken in November 2011, showed that the 'economy/recession' was identified as the single biggest obstacle to achieving business objectives by $60 \%$ of respondents (FSB, 2012). The British Chamber Quarterly Economic Survey for the second quarter of 2012 showed that all measures of business confidence were still below 2007 levels (BCC, 2012).

\section{Methodology}

The results have been generated from a survey of SMEs, named the "Local Economic Snapshot", in the English counties of Lincolnshire and Rutland. The survey was designed to provide quick feedback on business perceptions of the recession, and to track the effect of changing economic conditions and specific events on an ongoing basis. The survey results were used by the 
Lincolnshire and Rutland Employment and Skills Board and Lincolnshire County Council to inform policy, and by the University of Lincoln for analysis and wider dissemination.

The survey has been undertaken bi-monthly and has generated eleven sets of responses which represent two years of data from July 2010 to May 2012. The survey was started nine months after the UK officially emerged from 2008-09 recession in the third quarter of 2009, as graph 1 shows. The survey period therefore includes the period of recovery after the 2008-09 recession, as well as the two quarters of negative growth which saw the UK re-enter recession in the second quarter of 2012. The period of survey administration has therefore included periods of low and negative growth.

\section{Graph 1 - UK Gross Domestic Product and the period of survey administration}

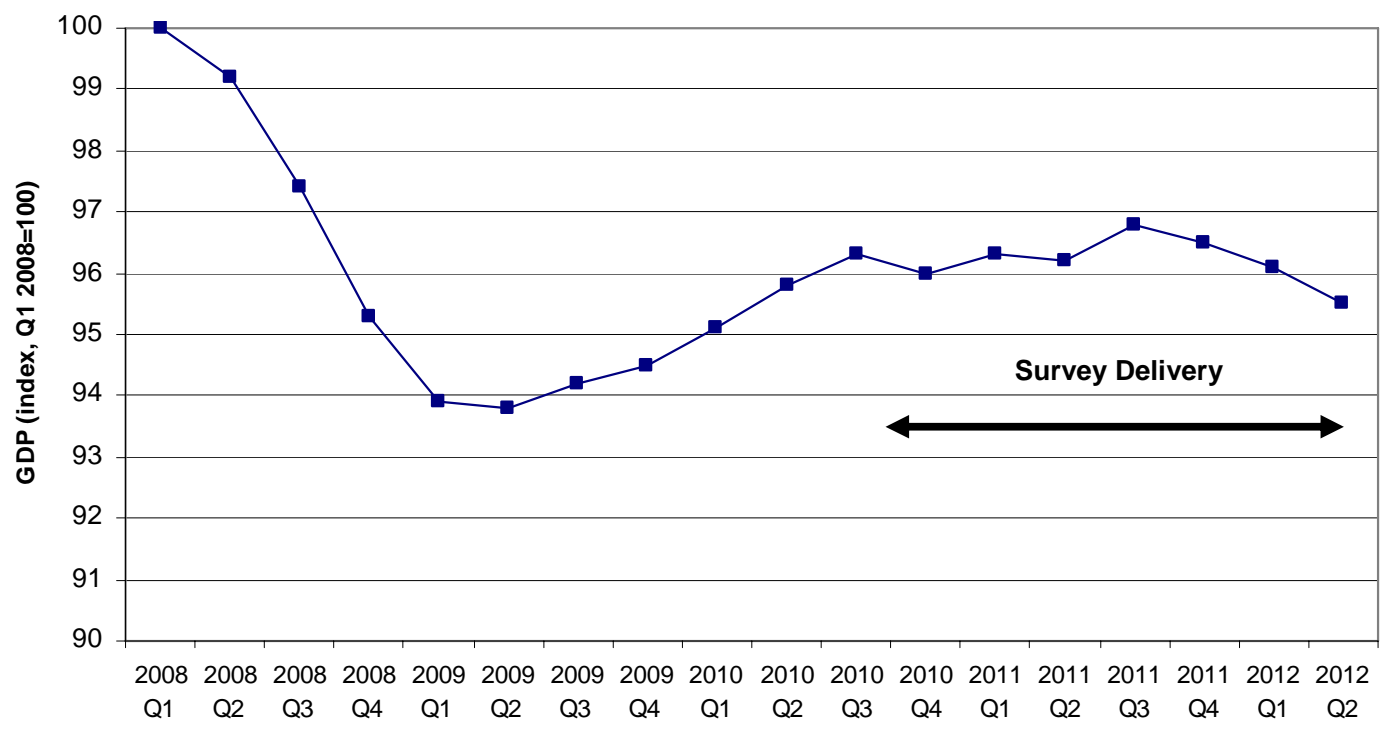

\section{Geographical Context}

Lincolnshire and Rutland are adjoining counties in the East Midlands region of England and, as such, comprise a continuous geographical area. The two are very different in size; while Lincolnshire is the fourth largest local authority area in England, Rutland is the smallest. They have, however, been frequently grouped together for business support and policy purposes. Lincolnshire and Rutland share a similar rural character. Using the DEFRA Rural Urban Classification (2009), both areas lack the presence of any area identified as 'major urban' or 'large urban'. Seven of the eight districts in the area are considered rural or significantly rural, with only Lincoln qualifying as an urban area. Lincolnshire can be regarded as a lagging area in economic terms, with GVA per head at $72 \%$ of the national average (ONS, 2009). GVA in Rutland is significantly more, at $94 \%$ of the national average, although this figure is for Leicestershire and Rutland combined (ibid). SMEs are strongly represented in the Lincolnshire and Rutland business population, accounting for $99.8 \%$ of all businesses (ONS, 2010). Employment in the public sector is higher than the national average, at $28 \%$ in Lincolnshire and 34\% in Rutland, compared with $27 \%$ across Great Britain (ONS, 2008).

\section{Sample Design}

The sample of firms was drawn from a variety of sources, including participants of Lincoln Business School programmes and local authority contacts. To ensure that the sample included a representative geographic and sector spread, additional business contacts were sourced from yell.com and a commercial business database. The survey was hosted using online survey software, surveymonkey. It is estimated that around $94 \%$ of local businesses currently have access to a broadband internet connection (Lincolnshire County Council, 2011), which means that the electronic survey approach is appropriate for the vast majority of SMEs in the area. However, 
although comprising a small proportion of the total, those with poor or no internet connectivity are concentrated primarily in rural areas of Lincolnshire and Rutland. To avoid the non-response bias associated with electronic surveys, the survey was also made available in paper form. It was promoted at University business events which took place throughout the two year period around the area, and was available to complete and return by post to ensure that those without internet access had the opportunity to participate.

Businesses were invited to take part in the survey using personalised email invitations. The email addresses identified were primarily for SME owner-managers, although also included some sales and finance contacts. The original email invitation was sent out to 1,616 businesses, and received 111 responses from SMEs, representing a response rate of $6.9 \%$. Each of the eleven sets of responses to the survey received between 67 and 111 responses, representing a response rate of between $4.1 \%$ and $6.9 \%$. This provided a sampling error of between $+/-9.3 \%$ and $+/-11.9 \%$, which assumes a maximum divergence of opinion, based on a confidence level of $95 \%$. For this reason, the commentary focuses on overall trends, rather than on differences between individual bi-monthly survey responses.

Tables 1 and 2 show details of respondents in the first survey in July 2010 and the final survey in May 2012. The majority, $65 \%$, of those that responded were from service sector firms, similar to the Lincolnshire and Rutland average. The response set has an over-representation of firms involved in construction (around 20\%) and manufacturing (11\%). There is an under-representation of agricultural businesses, at 3\% - 5\% compared with an average of $15 \%$ across the area.

Table 1 - Sector of Respondent Businesses

\begin{tabular}{|l|r|r|r|}
\hline Sector & $\begin{array}{r}\text { \% } \\
\text { respondents } \\
\text { in July 2010 }\end{array}$ & $\begin{array}{r}\text { \% respondents in } \\
\text { May 2012 }\end{array}$ & $\begin{array}{r}\text { \% in Lincolnshire } \\
\text { and Rutland (ONS, } \\
\text { 2010) }\end{array}$ \\
\hline Agriculture & 3.0 & 5.3 & 14.7 \\
\hline Construction & 21.2 & 19.3 & 11.6 \\
\hline Manufacturing & 11.1 & 10.5 & 6.9 \\
\hline Services & 64.7 & 64.9 & 66.8 \\
\hline
\end{tabular}

The response set is skewed towards smaller businesses, with micro-businesses (0-5 employees) and small businesses (between 6 and 50 employees) together accounting for $88 \%$ of respondents in the July 2010 survey, and $98.5 \%$ in the May 2012 survey. The size distribution fits broadly with the profile of businesses in Lincolnshire and Rutland, where $97 \%$ of businesses are small.

Table 2 - Size of Respondent Businesses

\begin{tabular}{|l|r|r|r|}
\hline $\begin{array}{l}\text { Number } \\
\text { Employees }\end{array}$ & $\begin{array}{r}\text { \% respondents } \\
\text { in July 2010 }\end{array}$ & $\begin{array}{r}\text { \% of respondents } \\
\text { in May 2012 }\end{array}$ & $\begin{array}{r}\text { \% SMEs in } \\
\text { Lincolnshire and } \\
\text { Rutland (ONS, 2010) }\end{array}$ \\
\hline $0-5$ & 44.3 & 58.5 & 67.7 \\
\hline $6-10$ & 21.7 & 21.5 & 15.9 \\
\hline $11-50$ & 21.7 & 18.5 & 13.9 \\
\hline $51-250$ & 12.3 & 1.5 & 2.5 \\
\hline
\end{tabular}

The survey received responses from across the area. $89 \%$ of respondents were from Lincolnshire, while $11 \%$ were based in Rutland. Just under half of respondents $(37 \%-50 \%$ over the course of the survey) were based in and around the main urban centre of Lincoln, with the remainder of responses from market towns and rural areas. The dataset shows a broad distribution across urban and rural areas, as Table 3 shows.

Table 3 - Rural/Urban Location of Respondent Businesses 


\begin{tabular}{|l|c|c|r|}
\hline $\begin{array}{l}\text { DEFRA (2009) Local } \\
\text { Authority } \\
\text { Rural/Urban } \\
\text { Classification }\end{array}$ & $\begin{array}{r}\text { \% respondents } \\
\text { in July 2010 }\end{array}$ & $\begin{array}{r}\text { \% of respondents } \\
\text { in May 2012 }\end{array}$ & $\begin{array}{r}\text { \% in Lincolnshire } \\
\text { and Rutland (ONS, } \\
\text { 2010) }\end{array}$ \\
\hline Other Urban & 42.9 & 53.5 & 20.5 \\
\hline Significant Rural & 7.1 & 4.1 & 5.8 \\
\hline Rural 50 & 17.1 & 12.3 & 27.8 \\
\hline Rural 80 & 33.2 & 30.1 & 45.9 \\
\hline
\end{tabular}

\section{Questionnaire Design}

The questionnaire comprised a core set of Likert-scale questions that would be tracked across the survey period. These were developed to measure the effect of the recession and the SME owner manager response, as identified through the literature, as well as business expectations. The external environment questions covered views on factors occurring outside the SME, such as public sector cuts, customer payments and access to finance. The questions on SME strategy covered both the revenue generating (such expanding activities, reaching new customers and engaging in international trade) and cost cutting approaches (such as reducing employee hours and workforce size). Each question was phrased as a simple statement to which respondents could agree or disagree, on a five point scale. The core set of questions are shown below:

Business expectations: $\quad$ The recession is over for my business Trading conditions are improving

The external environment: Public sector cuts are likely to have an adverse effect on my business Public sector cuts are already having an adverse effect on my business Customers are taking longer to pay

Finance for business is becoming easier to obtain

SME strategy:

I am expanding the activities in my business

My business is attracting new customers

Over the next 6 months, I will recruit additional staff

Over the next 6 months, I will reduce the size of my workforce

Over the next 6 months, I will increase the hours worked by employees

Over the next 6 months, I will decrease the hours worked by employees

My business is seeing an increase in international trade

The results have been analysed using graphs and tables which plot changes in response over the two year period of the survey. Key variables have been analysed using Pearson correlation coefficients to explore the relationship between SMEs' perceptions of the external environment and the actions they take within their business.

\section{Findings}

\section{The Recession and Trading Conditions}

Businesses were asked to indicate their agreement with the statement, "the recession is over for my business". This question was asked to explore confidence in the national economy and to understand whether SMEs identified with the timescale of the UK recession as defined using national GDP growth data. Throughout the period of the survey, the proportion of businesses that agreed with this statement has remained below $20 \%$. Although the proportion that felt the recession is over increased to 19\% during 2010, the trend in 2011 and 2012 has been negative, falling to 6\% in May 2012. Views on trading conditions have demonstrated a more erratic pattern during the two year period, increasing from 29\% in July 2010 to 39\% in March 2011, and decreasing to 23\% in May 2012.

Comparing the two measures, the proportion of businesses that feel trading conditions are improving is consistently higher than those that consider the recession to be over. This suggests 
that businesses distinguish between the wider economy ("the recession") and the economic environment in which their business operates. Secondly, over the course of the two year period, both indicators have demonstrated growth during the first year, reflecting an increase in optimism about the economy and trading conditions, and a return to a level below that of the first survey. This reflects the "double dip" nature of the recessionary period, with GDP falling by $1.4 \%$ over the previous three consecutive quarters (ONS, 2012b).

\section{Graph 2 - Views on the Economy and Trading Conditions}

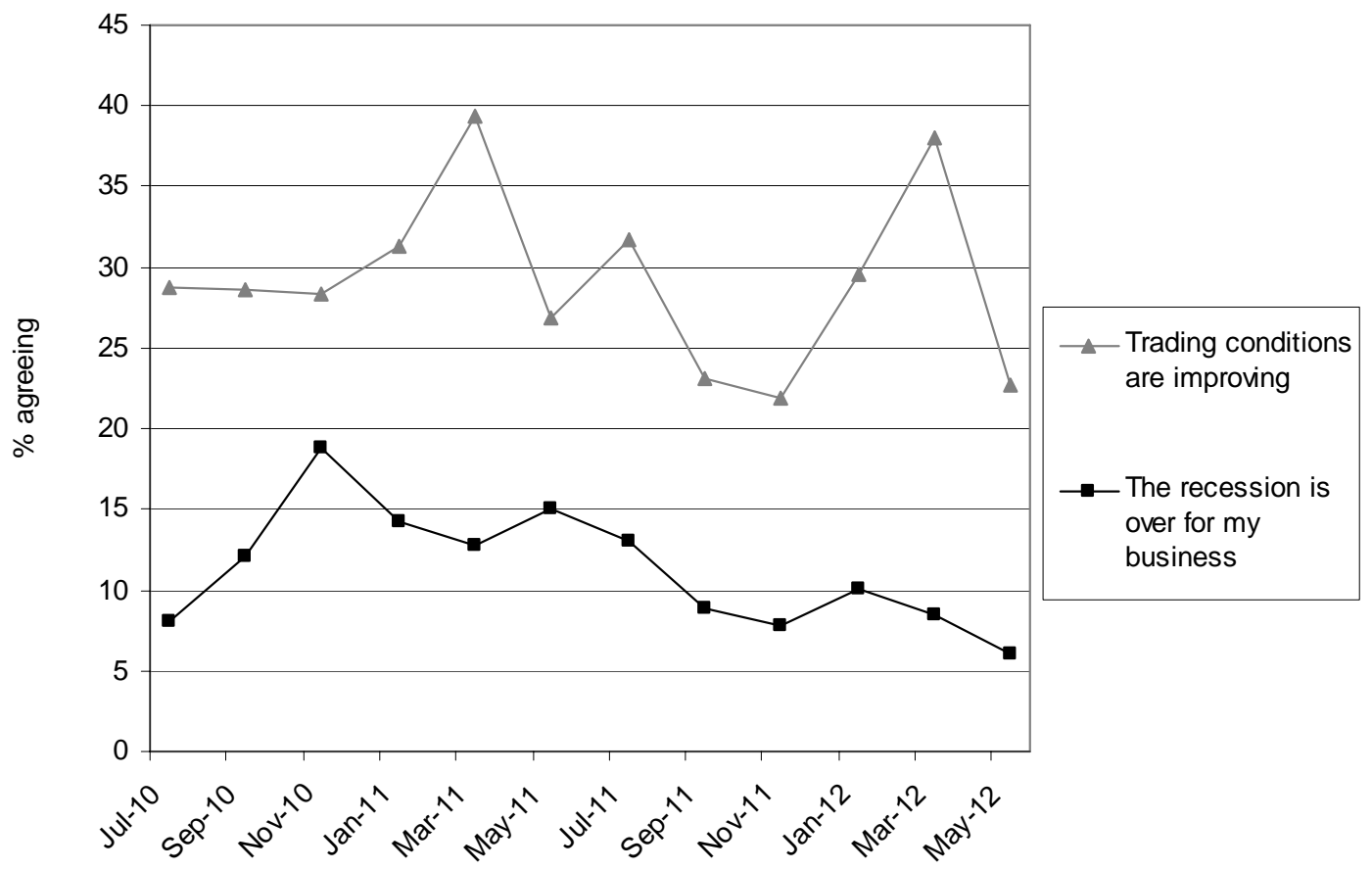

Graph 3 compares the proportion of respondents that consider the recession to be over for them with changes in quarterly national GDP, plotted for the middle month of each quarterly period. A Pearson correlation coefficient was computed to assess the relationship between national GDP results and the proportion of respondents that consider the recession to be over for them. This showed no correlation between the variables $(r=0.354, n=12, p=0.248)$. Looking at graph 3 , this may be because changes in SME views on the recession appear to lag changes in GDP at a national level. This may reflect the response of SMEs to media announcements of GDP output which occur in the month following the quarter-end. For example, the fourth quarter of 2010 saw a fall in national GDP but this was not reported until January 2011. 


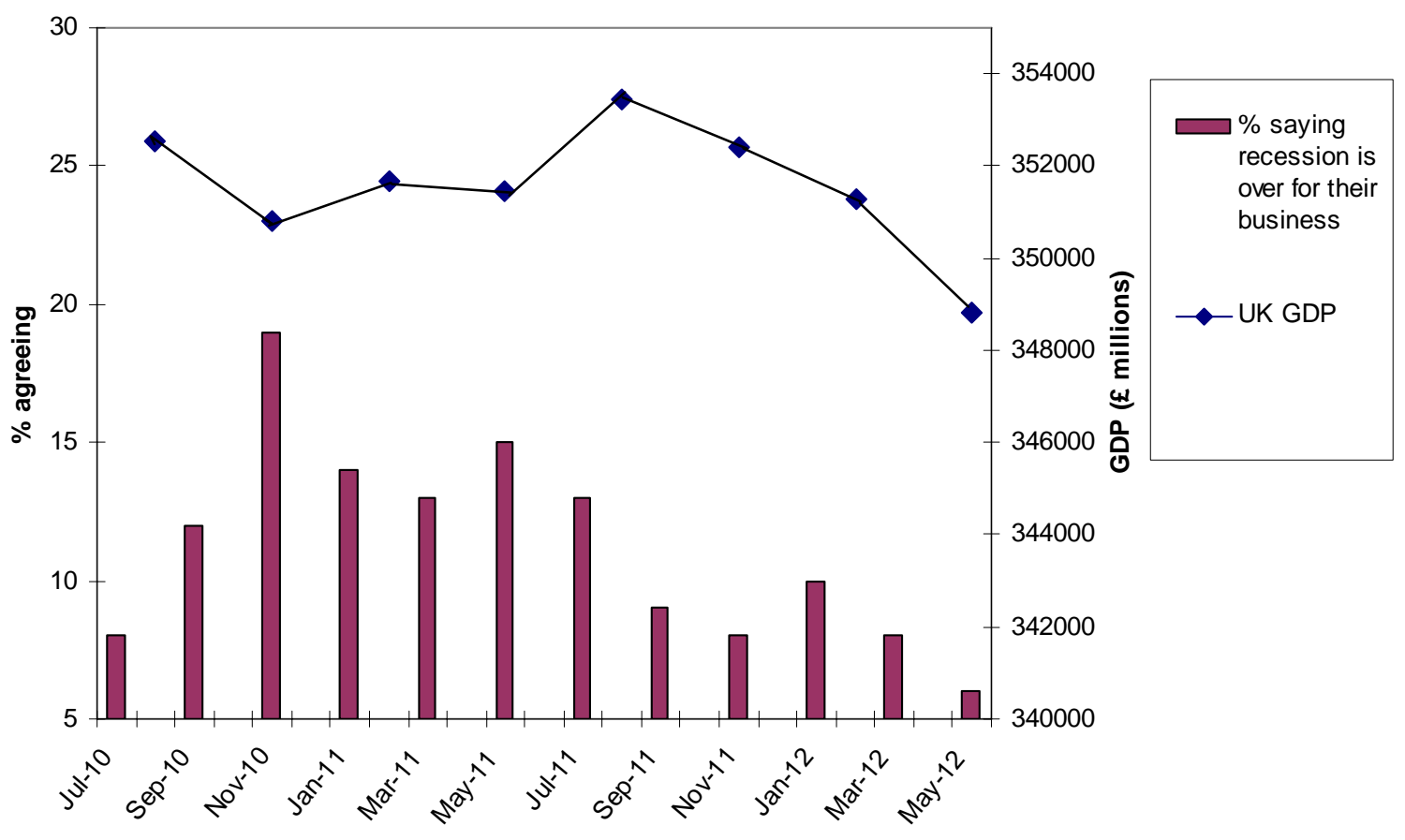

Public Sector Cuts

More than half, between $53 \%$ and $68 \%$ of respondents, have reported that public sector cuts are likely to have an adverse effect on their business. Given the high proportion of public sector employees in the local area, these results emphasise the perceived importance of the public sector to many SMEs. In the second year of the survey, respondents were also asked whether the cuts had already affected their business. The relationship between the responses to the two questions, shown in Graph 4, suggests that expectations have been borne in reality; an increasing proportion of SMEs (up to $62 \%$ by the end of the survey) have reported already being affected by the cuts. This suggests a period in which SMEs' negative expectations of public sector cuts have coincided with the reality of the cuts taking place and affecting their business. 


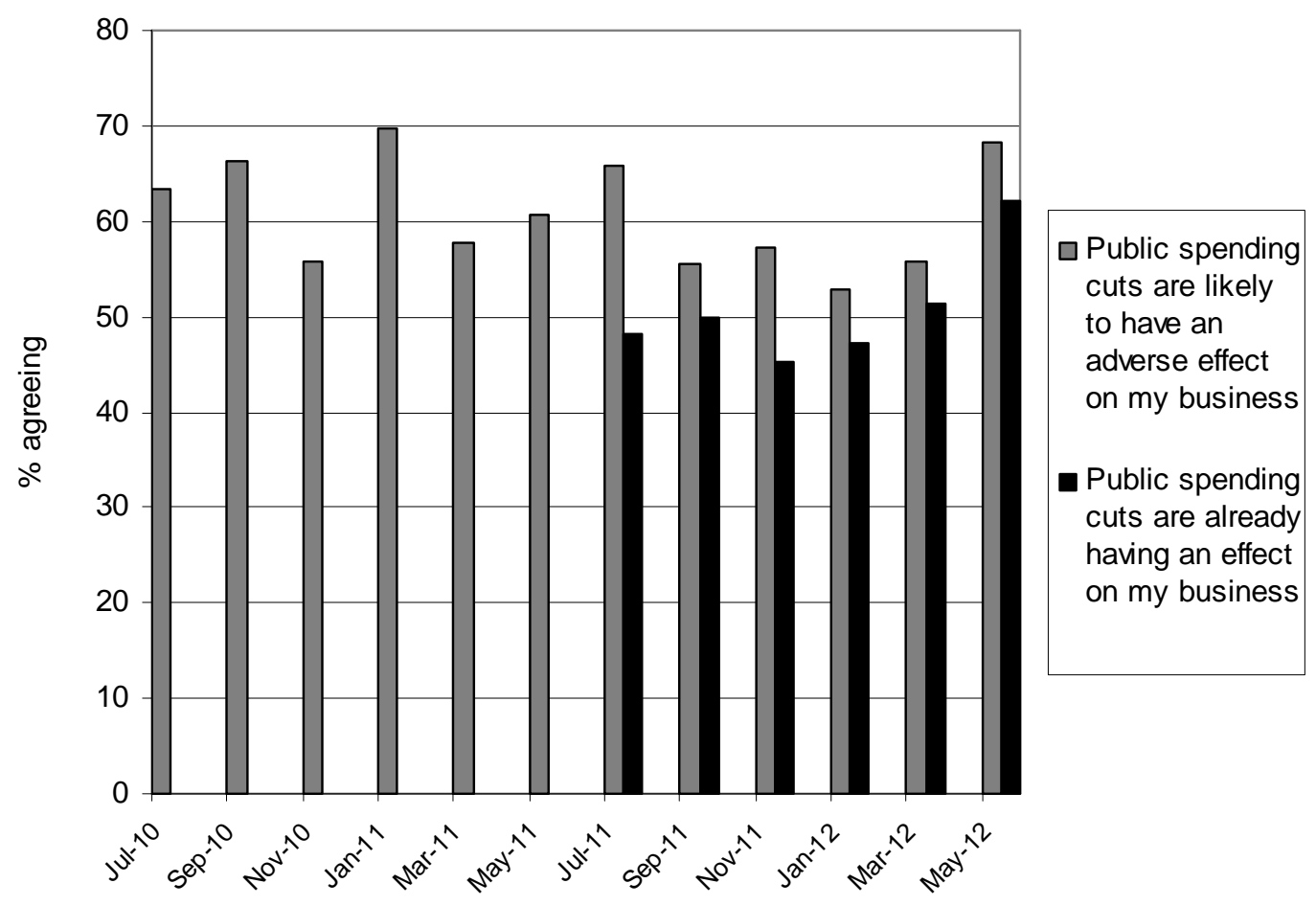

\section{Customer Payments and Finance}

More than half of respondents have reported that customers are taking longer to pay throughout the period, although this has declined slightly from 67\% in September 2010 to 53\% in May 2012. The proportion of businesses that feel finance has become easier to obtain has remained very low throughout, at between $1 \%$ and $10 \%$. Although the proportion of businesses that agree with this statement has undulated throughout the period, the overall trend has remained stable.

These results provide an indication of the long term consequences of the 'credit crunch' and suggest that banks are not promoting the availability of finance for business, nor making finance easy for SMEs to access. The findings are supported by the conclusions of Taylor and Bradley (1994) who state that the smaller size of SMEs means that they are perceived as a greater investment risk by finance providers. That more than half of respondents have observed later customer payments supports findings by Paul and Boden (2011) that late payment of debts has severely affected SMEs following the recession. 


\section{Graph 5 - Customer Payments and Access to Finance}

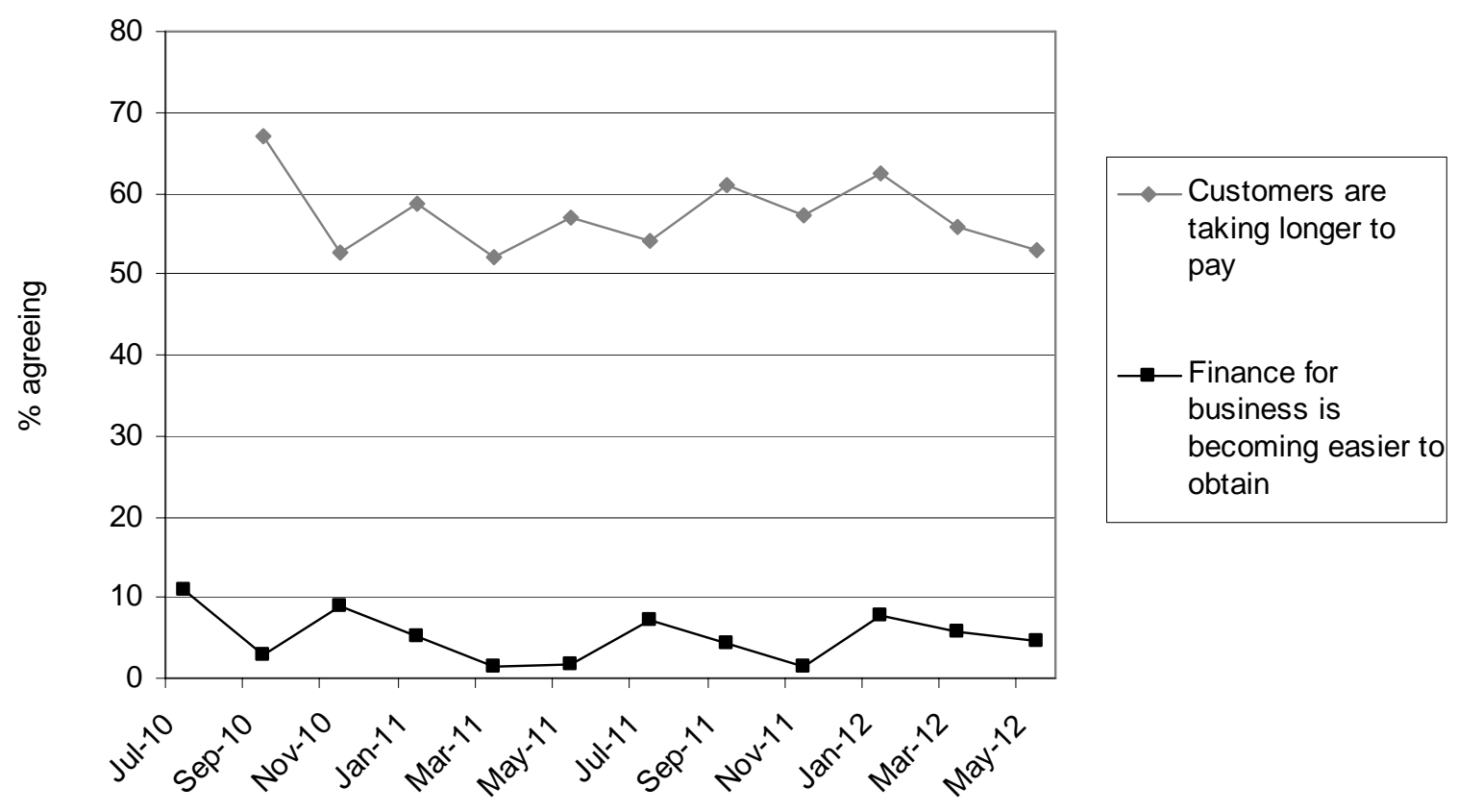

\section{Business Activity and Customers}

Despite low levels of optimism about the state of the economy, many respondents are expanding the activities in their businesses, and more than half say that they are attracting new customers. These businesses appear to demonstrate counter-cyclical optimism, in that they wish to continue to grow their business in adverse economic conditions. However, the expansion of business activity and customers could also be evidence of SMEs adopting revenue-generating responses to the recession, as discussed by Kitching et al (2011). The attraction of new customers is likely to be a key strategy for SMEs that have lost existing customers, and the expansion of business activities reflecting the need to identify more sustainable sources of revenue.

The overall proportion of businesses that say their business is attracting new customers dipped in May 2012 but remains the same as at the start of the survey at $63 \%$. The proportion of businesses saying that they are expanding the activities in their business has declined over the period of the survey; $61 \%$ were expanding the activities in their business in July 2010 , compared with $34 \%$ in May 2012. These findings may indicate a gradual change in consumer spending, as the volume of consumer spending was reported to be down during the first quarter of 2012 (ONS, 2012c). 


\section{Graph 6 - Business Activity and Customers}

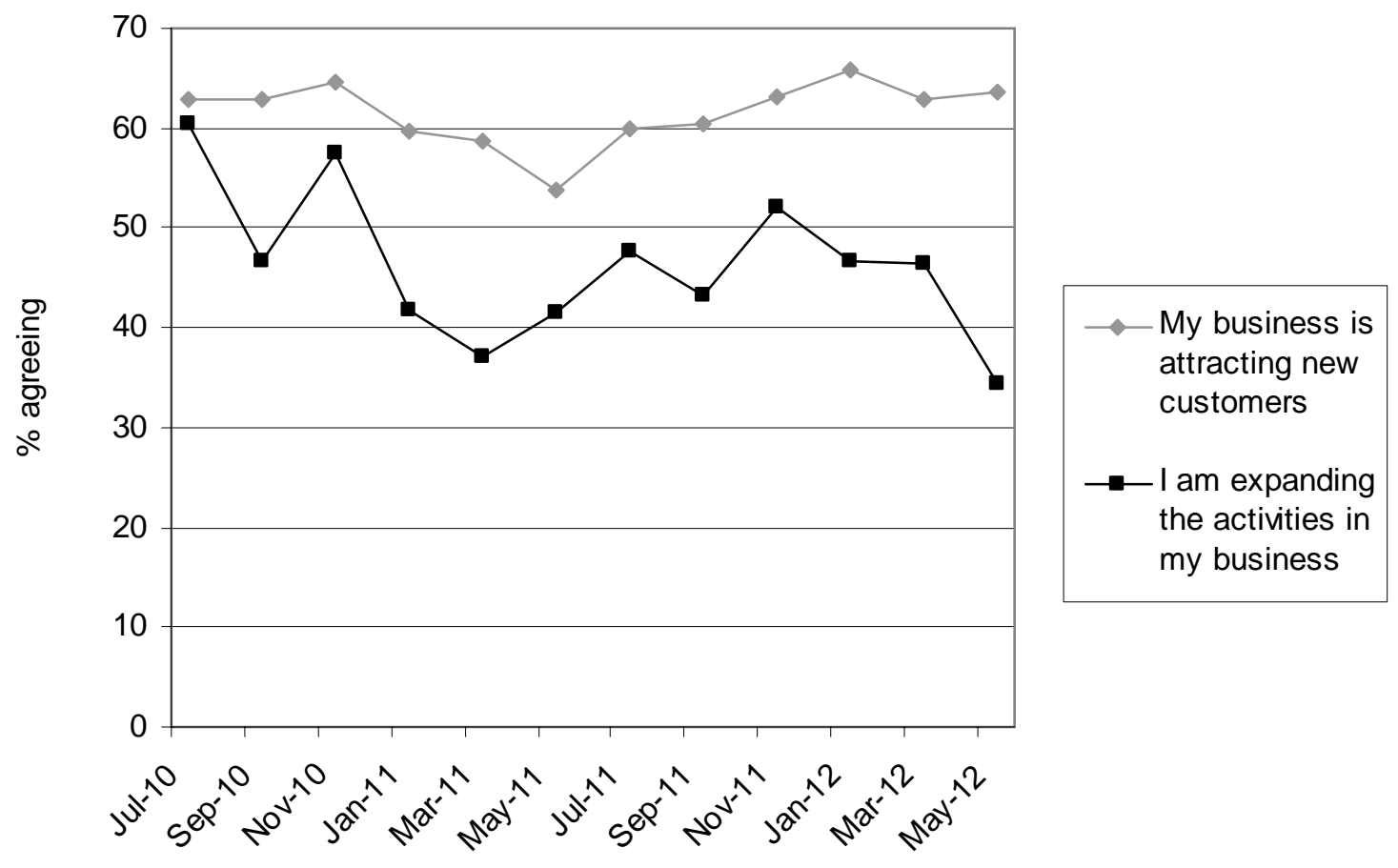

\section{Changes to the Workforce}

Businesses were asked whether they were likely to make any changes to their employees' hours or staffing levels over the next 6 months. Over the survey period, a greater proportion of businesses $(10 \%-25 \%)$ have indicated their intention to increase rather than decrease the hours worked by employees (4\% - 13\%). A greater proportion of businesses have also reported their intention to recruit additional staff $(17 \%-32 \%)$ rather than decrease their workforce $(4 \%-17 \%)$. These results reflect an emphasis towards revenue-generating, rather than cost-cutting, approaches in that the majority of SMEs are increasing or retaining the current capacity of their workforce.

The proportion of businesses intending to change their employees' hours or workforce size has fluctuated significantly over the two year period. Some of these changes may reflect seasonal fluctuations in demand, with the intention to increase staff and hours being greater around the January - May and lower in September - November. Over the survey period, however, there has been a significant decline in the number of businesses seeking to reduce the size of their workforce (from $17 \%$ to $3 \%$ ), and a slight reduction in number seeking to recruit additional staff (from $28 \%$ to $21 \%)$. This emphasises the earlier view that respondents are making fewer changes to the overall staffing of their businesses, and are instead aiming to retain their workforce capacity. 


\section{Graph 7 - Planned changes to Employee Hours in the next 6 months}

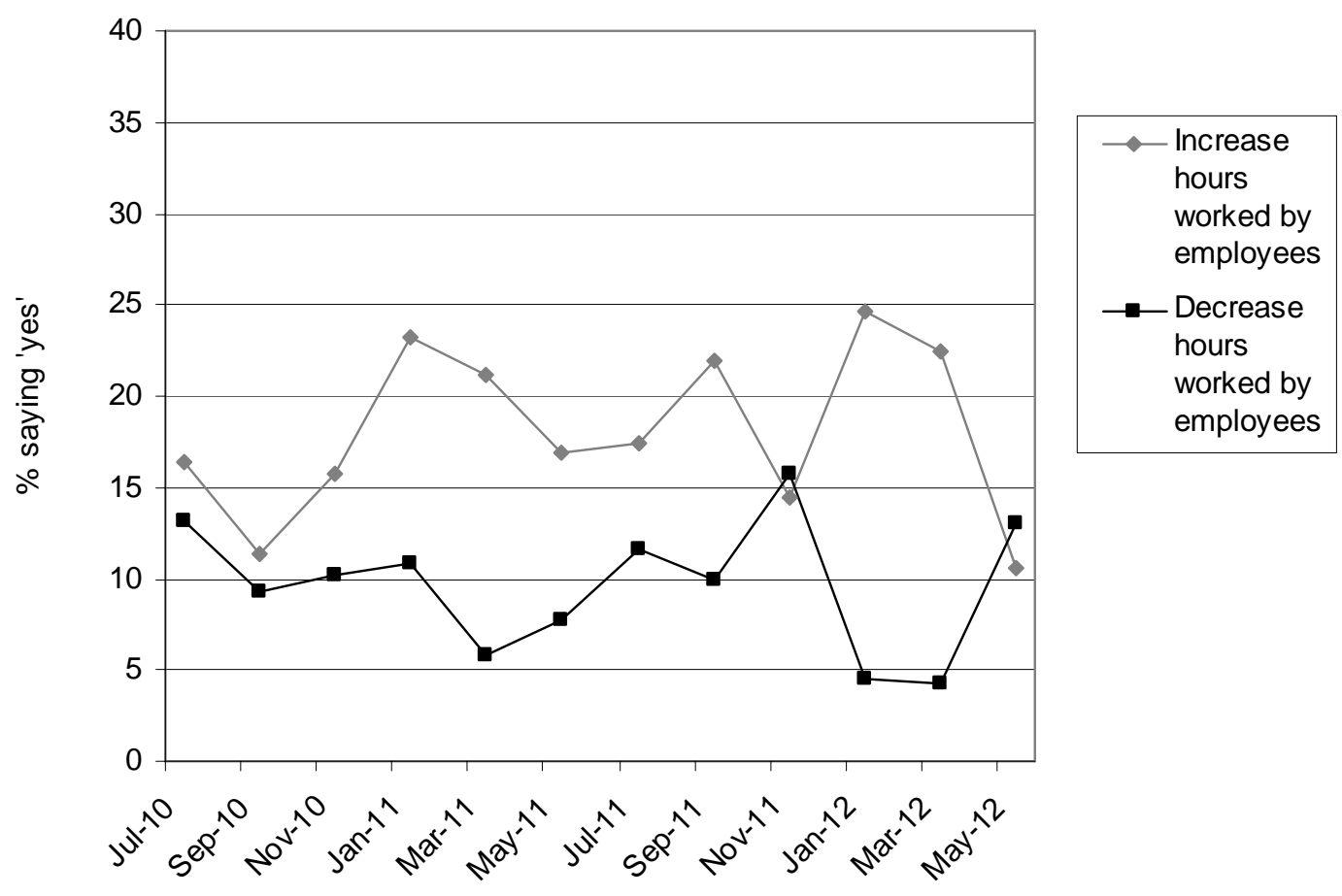

\section{Graph 8 - Planned changes to Workforce in the next 6 months}

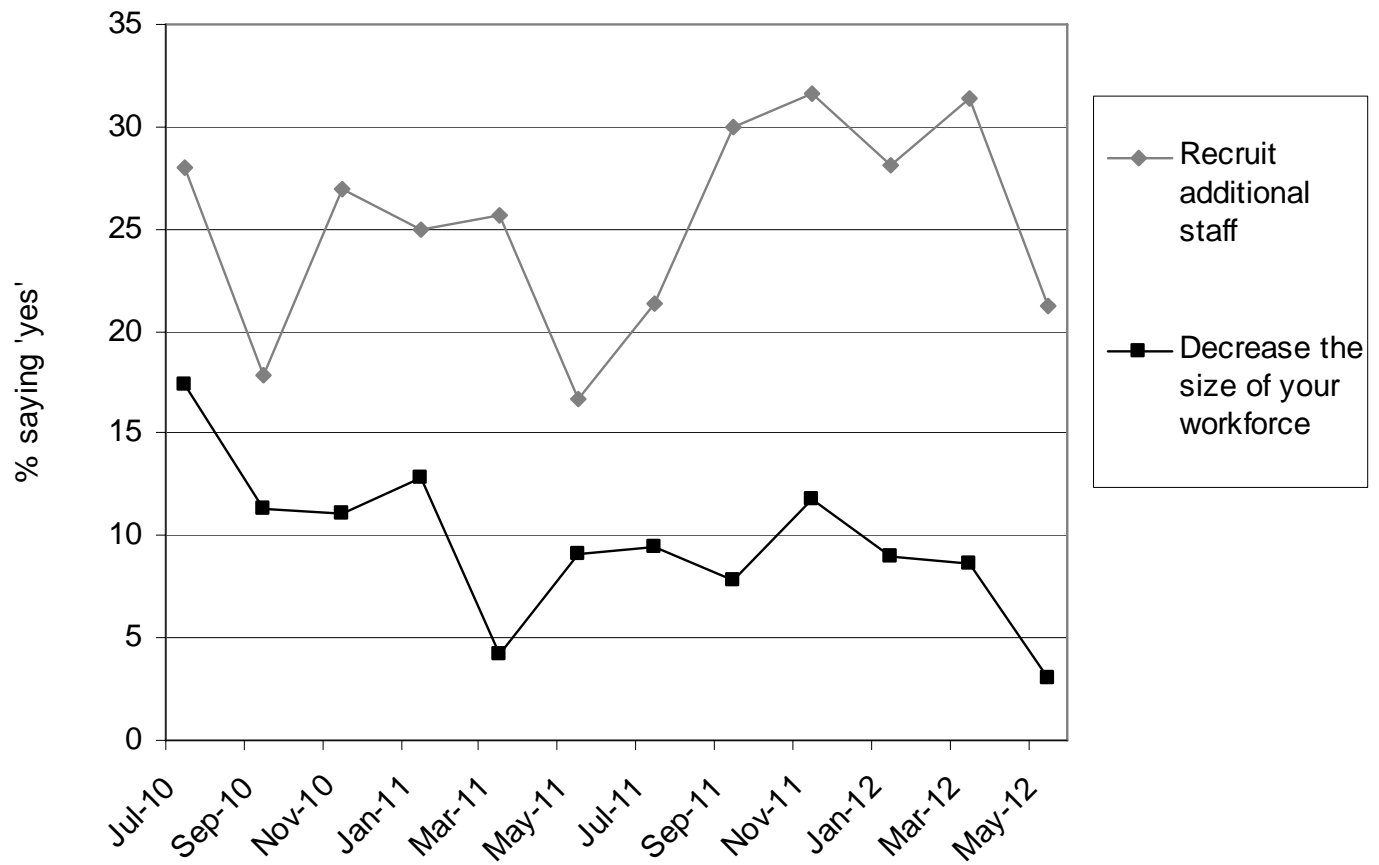

The Relationship between Perceptions and Response to the Recession

To explore the relationship between SMEs' perceptions of, and their response to, the recession, Pearson correlation coefficients have been computed for key variables. The correlation coefficients were applied, where available, across the twelve points for each variable over the two year period of 
the survey. The relationships that were identified as significant at the $95 \%$ level are shown in table 4 below:

Table 4 - Results of Pearson's correlation coefficients: relationships identified as significant at the 95\% level

\begin{tabular}{|l|l|l|l|}
\hline Variables & $\begin{array}{l}\text { Pearson's } \\
\boldsymbol{r}\end{array}$ & $\mathbf{n}$ & $\mathbf{p}$ \\
\hline $\begin{array}{l}\text { Trading conditions are improving vs I plan to reduce my } \\
\text { employees hours }\end{array}$ & -0.690 & 12 & 0.013 \\
\hline $\begin{array}{l}\text { Trading conditions are improving vs my business is seeing an } \\
\text { increase in international trade }\end{array}$ & 0.801 & 6 & 0.050 \\
\hline $\begin{array}{l}\text { I am expanding the activities in my business vs I plan to reduce } \\
\text { the size of my workforce }\end{array}$ & 0.820 & 12 & 0.001 \\
\hline $\begin{array}{l}\text { Public sector spending cuts are likely to have an adverse effect on } \\
\text { my business vs I plan to recruit additional staff }\end{array}$ & -0.606 & 12 & 0.037 \\
\hline $\begin{array}{l}\text { Finance is becoming easier to obtain vs I am expanding the } \\
\text { activities in my business }\end{array}$ & 0.612 & 12 & 0.034 \\
\hline
\end{tabular}

Analysis of the Pearson correlation results reveals a number of key points about the relationship between SMEs' expectations about the economy and the strategies they adopt within their business. The first is that there is no significant relationship between SMEs' views on whether the recession is over and any other variable. This suggests that expectations about national economic conditions are less important than might be expected in influencing the strategies that SMEs take.

By contrast, views on trading conditions are a more significant factor. There is a negative relationship between views on trading conditions and plans to reduce employees' hours. Decisions to reduce employees' hours are therefore more likely to be influenced by owner managers' perceptions of the environment in which their business trades than of the wider economy. Perhaps expectedly, views on trading conditions are strongly correlated with levels of engagement in international trade. This suggests that some of the difference between views on "the recession" and "trading conditions" may be explained by the perception that international trading conditions are improving.

Views on whether public sector cuts are likely to have an adverse effect on business are shown to have a negative relationship with SMEs' plans to recruit additional staff. This implies that SMEs' expectations about public sector cuts may affect their recruitment decisions, with those that are concerned about the prospective adverse effects of the cuts less likely to recruit additional staff over the next 6 months.

While experience of customer payments is not shown to be related to any other variable, access to finance is. The strong correlation of access to finance with SMEs intending to expand business activities suggests that owner managers may be seeking finance at moments when they are exploring new sources of revenue. Lack of access to finance may, in turn, impede SMEs' abilities to expand the activities in their business. Interestingly, SMEs' intentions to expand their business activities is strongly correlated with plans to reduce the size of the workforce. This reinforces the earlier suggestion that the strategy to expand business activity is not necessarily about business growth, but about securing alternative forms of revenue at difficult moments.

\section{Discussion}

The survey findings show that, throughout the period between July 2010 and May 2012, the majority of respondents continued to feel that the recession was not yet over for their business. The findings reinforce predictions by the IMF (2012) that growth is likely to remain subdued well into 2012, and the view of the Institute for Fiscal Studies that the recession "has cast a very long shadow in the UK" (IFS, 2011: 20). 
Despite low optimism about the state of the economy, businesses appear to differentiate between wider economic conditions and the environment in which their business trades. This distinction may reflect the different sources of information that inform their perceptions of each. Their perception of the recession may be informed by time-lagged data reporting and also the media-led focus on the negative aspects of economic changes. Perceptions of trading conditions are perhaps more influenced by observation of changes that affect the day-to-day running of the business, including engagement in international trade.

The prospect of public sector cuts has continued to be a concern for businesses throughout the period of the survey. This reinforces the findings of PWC (2010) that businesses reliant on the public sector, through public sector contracts or expenditure by public sector employees, have been severely affected during this recent recession. Our analysis shows that SMEs are starting to feel the effects of public sector cuts, with a shift away from expectations towards a sense that the cuts are already affecting their business. Late customer payments and poor access to finance are also reported by the majority of respondents throughout the two year period.

In terms of owner manager response to the recession, the survey results suggest an emphasis towards revenue-generating rather than cost-cutting approaches. Around half of businesses have shown a commitment to expand the activities in their business despite acknowledging the presence of adverse economic conditions. This suggests that entrepreneurial growth opportunities continue to be recognised and acted upon during periods of recession. Similarly, a greater proportion of businesses plan to increase the hours worked by employees or recruit additional staff, than reduce hours or decrease the size of their workforce. Across almost all these measures, however, a decline can be observed from January 2012 onwards. This could suggest that businesses are retaining the existing capacity of their workforces, or that they are choosing to make fewer changes to their business as the UK re-enters recession. This is supported by research by the Chartered Institute of Personnel and Development (CIPD, 2012) which shows a third of firms are maintaining staff levels above what is needed to avoid losing workforce skills but will need to make job losses if the recession continues.

Considering the relationship between business confidence and growth intentions, the survey findings indicate that GDP growth data and views on the recession are shown to be less strongly related to business decisions than views on trading conditions and public sector cuts. These results suggest that the behaviour of SME owner managers is more closely rooted in experience and/or anticipation of events that directly affect them rather than the anticipation of changes in the wider economy. The results emphasise that business expectations about the wider economy are indeed, as Wheeler (2010) suggests, not necessarily an indicator of business growth and may produce a 'false signal'.

The findings suggest that access to finance continues to be an important factor in business survival; the strong correlation of access to finance with SMEs intending to expand business activities suggests that owner managers may be seeking finance at moments when they are exploring new sources of revenue. Lack of access to finance may, in turn, impede SMEs' abilities to expand the activities in their business.

\section{Conclusions}

At a time when there are few publications on the effect of the 2008-09 recession on businesses, the findings set out in this paper provide timely insights into SMEs' perceptions of these economic conditions and their confidence for business growth. The longitudinal nature of the survey has provided the opportunity to track views on the effects of the recession over a two year period. The survey data has provided a benchmarking tool for participating SMEs in Lincolnshire and Rutland, and by the local Employment and Skills Board to gain a greater understanding of changes within the labour market, and to forecast demand for recruitment and training services.

The emphasis on business expansion highlighted by the survey reflects the 'instinctive' determination of SMEs to survive, however, and a strong level of resilience and adaptability, as 
Anderson \& Russell (2009) have suggested. The desire of SME owner managers to grow their way out of difficult economic times is clear, and is one where policymakers could assist. The period since January 2012 has seen a decline in SMEs expanding the activities in their business, however, with a shift towards maintaining current capacity.

The survey highlights a number of external factors that have had a prolonged effect on SME owner managers' plans for their business. Access to finance is identified as a clear precursor to business expansion, but SMEs reporting easy access to finance has remained low over the period. The findings suggest that SMEs, as Sahin et al (2011) suggest, continue to be considered an investment risk by banks, and that there has been little change in the availability of finance for business throughout the period of the survey. Given the link between access to finance and business expansion, and therefore employment and economic growth, this puts the impetus on policymakers to identify and promote alternative financing models for SMEs. The Government's Business Growth Initiative and National Loan Guarantee Scheme are examples, but are focused towards larger businesses with significant growth potential. The financing needs of SMEs are more likely to be met by providers of smaller funding amounts, which include private equity funders, local authority loan funds and online sources such as crowd funding.

The loss of public sector revenue is clearly restricting the ability of SMEs to grow during the recessionary period. As in Lincolnshire and Rutland, this is likely to be the case in other peripheral areas that have developed an increasing reliance on the public sector. The findings support the view of Martin (2011) that the economic structure of a region affects its ability to respond to economic shocks. For SMEs to grow in areas in these peripheral areas, there is a need to identify new sources of revenue and refocus business models. The business development programme, Business Inspiration, which was delivered by the University of Lincoln during the course of the survey, shows that there is continued demand for support that helps businesses to clarify the focus of their activities and develop more sustainable business models (Rae et al, 2012). However, the ability of SMEs to participate in such programmes is restricted by their own limited resources, and a reduction in funding for mainstream business support.

SMEs are identified by both Government and academics as vital to future UK growth and productivity (BIS, 2009; Matlay, 2012). However, with a loss of public sector revenue and restricted access to finance, the continued growth of the SME sector and its contribution to the economic recovery cannot be assumed. The need for policymakers to assist SMEs in exploring alternative business models and revenue sources is clearly identified through the findings outlined here, and is arguably a pre-condition for a return to national economic growth. 


\section{References}

Anderson, A. and Russell, E. (2009) "Small Businesses In Economic Adversity; Impact, Affect And Responses", Paper presented at Institute for Small Business and Entrepreneurship Conference, Liverpool, November 2009.

Anderson, A., Ossiechuk, E. and Illingworth, L. (2010), "Rural small businesses in turbulent times; impacts of the economic downturn", Entrepreneurship and Innovation Vol 11, No 1, pp 45-56.

Audas, R. and MacKay, R. (1997), "A Tales of Two Recessions", Regional Studies, Vol. 31, No 9, pp 867-874.

Athey, G. (2009), "Economic Development in the UK: Challenges During and After the Recession", Local Economy, Vol. 24, Nos. 6-7, pp 604-611.

Bank of England (2010) Agents' Summary of Business Conditions, January 2009, 2010, 2011

British Chamber of Commerce (2012) Summary: Quarterly Economic Survey, Q1 2012

Cabinet Office (2011) Public Bodies Reform - Proposals for Change, March 2011

Chartered Institute of Personnel and Development (CIPD), (2012) Press Release: Quarterly Labour Market Outlook explains gravity defying labour market, accessed online 13 August 2012:

http://www.cipd.co.uk/pressoffice/press-releases/quarterly-labour-market-outlook-explains-gravitydefying-labour-market-130812.aspx

Chow, M.J., and Dunkelberg, W.C. (2011) "The Small Business Sector in Recent Recoveries", Business Economics, Vol 46, No. 4

Cosh, A., and Hughes, A., eds (2000), British Enterprise in Transition: Growth, Innovation and Public Policy in the Small and Medium Sized Enterprise Sector 1994-1999, University of Cambridge ESRC Centre for Business Research, Cambridge.

Davis, I. (2009) "The New Normal", McInsey Quarterly, March 2009

De Jorge Moreno, J., Laborda Castillo, L. De Zuani Masere, E. (2007) "Influenced of entrepreneur type, region and sector effects on business self-confidence: Empirical evidence from Argentine firms", Entrepreneurship and Regional Development, Vol. 19, pp 25-48

Department for Business Innovation and Skills (BIS) (2009) The provision of growth capital to UK Small and Medium sized Enterprises

Department for Business Innovation and Skills (BIS) (2011) Business Population Estimates for the UK and Regions

DEFRA (2009) Introductory Guide to Rural-Urban Classification of LAs, accessed online: http://www.defra.gov.uk/statistics/rural/what-is-rural/rural-urban-classification/

Dixon, R. (2007), "Regional Differences in the Severity of Recessions in the United Kingdom", Australasian Journal of Regional Studies, Vol. 13, Issue 3, pp 351-371.

Hills, S., Thomas, R., Dimsdale, N. (2010) "The UK recession in context: what do three centuries of data tell us?", Research and Analysis: Quarterly Bulletin from the Bank of England

Institute for Fiscal Studies (2011) The Great Recession and the Distribution of Household Income, funded by Italian Research Institute, The Fondazione Rodolfo Debenedetti

IMF (2012) World Economic Outlook, April 2012, International Monetary Fund, Washington DC, accessed online 25 July 2012: http://www.imf.org/external/pubs/ft/weo/2012/01/pdf/c2.pdf

FSB (2011) "Late payments still hurting small firms shows FSB Research", accessed online on 13 July 2011: http://www.fsb.org.uk/news.aspx?REC=7169

FSB (2012) The FSB 'Voice of Small Business' Member Survey, accessed online 25 July 2012: http://www.fsb.org.uk/policy/assets/uk\%20voice\%20of\%20small\%20business\%20member\%20sur vey\%20report\%20feb\%202012.pdf

Judd, R. and Lee, C. H. (1981) "Financial Concerns and Business Strategies during Inflation/Recession: Perceptions by Business Owner/Managers" Journal of Small Business Management, October 1981

Kitching, J., Smallbone, D. Xheneti, M., Kasperova, E. (2011) "Adapting to a Fragile Recovery: SME Responses to Recession and Post-Recession Performance", presented to the Small Business and Entrepreneurship Conference, Sheffield, November 2011

Lincolnshire County Council (2011) Broadband Plan for Lincolnshire

Martin, R. (2011), "Regional Economic Resilience, Hysteresis and Recessionary Shocks", Plenary Paper Presented at the Annual International Conference of the Regional Studies Association, Newcastle, 17-20 April, 2011.

Matlay (2012) "Editorial", Journal of Small Business and Enterprise Development, Vol. 19, Issue 2 Office for Budget Responsibility (2011) Economic and Fiscal Outlook, November 2011 
ONS (2008) Annual Business Inquiry Employee Analysis

ONS (2009) NUTS3 Regional GVA 1997-2009

ONS (2010) UK Business: Size, Sector and Activity: 2010

ONS (2011) Output in the Construction Industry: Statistical Bulletin Q1

ONS (2012a) GDP Growth, accessed online on 25 July 2012:

http://www.statistics.gov.uk/cci/nugget.asp?id=192

ONS (2012b) GDP and the Labour Market - 2012 Q2 - July GDP Update, accessed online 27 July

2012: http://www.ons.gov.uk/ons/dcp171780 274200.pdf

ONS (2012c) Consumer Trends, Quarter 1, 2012

Oxford Economics (2009) "Will the recession bring about a rebalancing of the UK economy?", Economic Outlook, July 2009

Paul S. and Boden R. (2011) "Taking the Credit" in Enterprise Matters, Institute for Small Business and Entrepreneurship, Spring 2011

Piercy, N., Cravens, D. and Lane, N. (2010) "Marketing out of the recession: recovery is coming but things will never be the same again", The Marketing Review, Vol. 10, Issue 1, pp 3-23

Price Waterhouse Coopers (2010) UK Economic Outlook 2010

Rae, D (2010) "Universities and enterprise education: responding to the challenges of the new era", Journal of Small Business \& Enterprise Development, Vol. 17 Issue: 4, pp.591 - 606

Rae, D., Price, L., Bosworth, G. and Parkinson, P, (2012) "Business Inspiration: Small business leadership in recovery?" Industry \& Higher Education, Vol. 26, Issue 6, pp 473-489

Sahin, A., Kitao, S., Cororaton, A. and Laiu, S (2011) "Why Small Businesses Were Hit Harder by the Recent Recession", Current Issues in Economics and Finance, Vol. 17, No. 4

Social Issues Research Centre (2009) Generation Recession: A report by the Social Issues Research Centre commissioned by Friends Provident

Simons (2009) "Food retail offers hope to agencies" Recruiter, February 2009

Smallbone, D., North, D and Kalantaridis, C (1999) "Adapting to peripherality: a study of small rural manufacturing firms in northern England" Entrepreneurship and Regional Development, Vol. 11, pp 109-127

Stone, J.H., (1975) "Small Business Management in a Recession", Journal of Small Business Management

Storey, D. J. (2011) "Optimism and chance: The elephants in the entrepreneurship room", International Small Business Journal, Vol. 29, Issue 4, 303-320

Taylor, J. and Bradley, S. (1994), "Spatial Disparities in the Impact of the 1990-1992 Recession: An Analysis of UK Counties", Oxford Bulletin of Economics and Statistics, Vol. 56, pp 367-382

Wheeler, T. (2010) "What can we learn from surveys of business expectations?", Bank of England Quarterly Bulletin, 2010 Q3 